\title{
Assessment and partial purification of serine protease inhibitors from Rhipicephalus (Boophilus) annulatus larvae
}

\author{
Avaliação e purificação parcial dos inibidores da serina protease de \\ larvas do Rhipicephalus (Boophilus) annulatus \\ Sedigheh Nabian ${ }^{1,2 *}$; Mohammad Taheri ${ }^{3}$; Mohammad Mehdi Ranjbar ${ }^{4}$; Alireza Sazmand ${ }^{5,6}$; \\ Parastou Youssefy ${ }^{3}$; Gholam Reza Nazaralipour ${ }^{1}$
}

\begin{abstract}
${ }^{1}$ Department of Parasitology, Faculty of Veterinary Medicine, University of Tehran - UT, Tehran, Iran
${ }^{2}$ Iranian Research Center for Tick and Tick- borne Diseases, Tehran, Iran

${ }^{3}$ Rastegar Reference Laboratory, Faculty of Veterinary Medicine, University of Tehran - UT, Tehran, Iran

${ }^{4}$ Department of Microbiology, Faculty of Veterinary Medicine, University of Tehran - UT, Tehran, Iran

${ }^{5}$ Institute of Parasitology, Department of Pathobiology, University of Veterinary Medicine Vienna - Vetmeduni Vienna, Vienna, Austria

${ }^{6}$ Department of Agriculture, Payame Noor University - PNU, Tehran, Iran
\end{abstract}

Received December 18, 2013

Accepted April 1, 2014

\begin{abstract}
Ticks are rich sources of serine protease inhibitors, particularly those that prevent blood clotting and inflammatory responses during blood feeding. The tick Rhipicephalus (Boophlus) annulatus is an important ectoparasite of cattle. The aims of this study were to characterize and purify the serine protease inhibitors present in $R$. (B.) annulatus larval extract. The inhibitors were characterized by means of one and two-dimensional reverse zymography, and purified using affinity chromatography on a trypsin-Sepharose column. The analysis on one and two-dimensional reverse zymography of the larval extract showed trypsin inhibitory activity at between 13 and $40 \mathrm{kDa}$. Through non-reducing SDS-PAGE and reverse zymography for proteins purified by trypsin-Sepharose affinity chromatography, some protein bands with molecular weights between 13 and $34 \mathrm{kDa}$ were detected. Western blotting showed that five protein bands at 48, 70, 110,130 and $250 \mathrm{kDa}$ reacted positively with immune serum, whereas there was no positive reaction in the range of $13-40 \mathrm{kDa}$. Serine protease inhibitors from $R$. (B.) annulatus have anti-trypsin activity similar to inhibitors belonging to several other hard tick species, thus suggesting that these proteins may be useful as targets in anti-tick vaccines.
\end{abstract}

Keywords: Rhipicephalus (B.) annulatus, serine protease inhibitors, zymography.

\section{Resumo}

Carrapatos são uma rica fonte de inibidores da serina protease, particularmente aqueles que previnem coagulação e respostas inflamatórias durante a alimentação com sangue. O carrapato Rhipicephalus (B.) annulatus é um ectoparasita importante de bovinos. O objetivo deste estudo foi caracterizar e purificar os inibidores da serina protease presentes no extrato de larva do $R$. (B.) annulatus. Os inibidores foram caracterizados através de zimografia reversa uni e bidimensional e purificados com cromatografia de afinidade em uma coluna de sepharose-tripsina. A análise do extrato de larva pela zimografia reversa uni e bidimensional mostrou atividade inibitória de tripsina entre 13 e $40 \mathrm{kDa}$. Através de SDS-PAGE e zimografia reversa para proteínas purificadas pela cromatografia por sepharose-tripsina, algumas bandas de proteínas com pesos moleculares entre 13 e $34 \mathrm{kDa}$ foram detectadas. Western blotting mostrou que cinco bandas de proteínas a 48, 70,110, 130 e $250 \mathrm{kDa}$ reagiram positivamente com o soro imune, enquanto não houve reação positiva nas bandas $13-40 \mathrm{kDa}$. Inibidores da serina protease do $R$. (B.) annulatus têm atividade antitripsina semelhante àquelas dos inibidores de outras espécies de carrapatos duros, sugerindo, assim, que essas proteínas podem ser úteis como alvo de vacinas contra carrapatos.

Palavras-chave: Rhipicephalus (B.) annulatus, inibidores da serina protease, zimografia.

\footnotetext{
*Corresponding author: Sedigheh Nabian

Department of Parasitology, Faculty of Veterinary Medicine, University of

Tehran - UT, Qareeb Street, Azadi Av., Tehran, Iran

e-mail: nabian@ut.ac.ir
} 


\section{Introduction}

Ticks are the most frequent ectoparasites that infest mammals, birds, reptiles and amphibians (SAUER et al., 1995). In Iran, Rhipicephalus annulatus (formerly Boophilus annulatus) is one of the most common ticks in cattle. This tick has also been recorded in some regions of Europe and the Americas, such as; Portugal, Spain, Italy, Greece, Turkey and Mexico; furthermore, it is common in northern Africa.

Ticks cause serious economic losses among cattle because of their blood-sucking activities and consequent transmission of some tick-borne diseases such as babesiosis and anaplasmosis (ESTRADA-PENAA et al., 2004). Therefore, controlling them has become a priority in tropical and subtropical regions. Tick control is mainly based on acaricides. Because of the disadvantages of acaricides, which including pollution of the environment and food chain and also acaricide resistance (PREVOT et al., 2007), alternative control methods such as vaccination are promising. Development of vaccines relies on obtaining more knowledge about tick proteins. Proteases and their inhibitors may be candidates for designing vaccines.

Ticks' success in blood sucking is due to the anti-hemostatic and anti-inflammatory substances present in tick saliva (AROCHAPIÑANGO et al., 1999). These insects are rich source of different serine protease inhibitors, which are distributed in tick tissues over the course of development of ticks' life cycle (VERMEULEN et al., 1988). Proteinase inhibitors have long been recognized in eggs and larvae of $R$. (B.) microplus, and have been seen to inhibit trypsin, chymotrypsin, elastase and plasma kallikrein (TANAKA et al., 1999). Interestingly, some inhibitors have been shown to prolong the activated partial thromboplastin time (APTT) and prothrombin time (PT) for bovine blood (IBRAHIM et al., 2001). These inhibitors, which are present in different ticks' tissues, can also protect these arthropods from infection by different pathogens (KANOST, 1999).

In this study, serine protease inhibitors in unfed larvae of $R$. (B.) annulatus were characterized by means of one and two- dimensional reverse zymography and purified using trypsin-Sepharose affinity chromatography.

\section{Materials and Methods}

\section{Ticks}

The $R$. (B.) annulatus ticks were handled as described by Brown et al. (1984). The tick larvae were obtained by incubating engorged females at $85 \%$ relative humidity and $28{ }^{\circ} \mathrm{C}$. Two healthy seronegative four-month-old Holstein calves were provided for tick infestation. Each calf was infested with about 10,000 R. (B.) annulatus larvae. The larvae from the engorged ticks were collected ten days after eclosion and stored at $-20^{\circ} \mathrm{C}$.

\section{Protein extraction}

Tick larvae $(0.1 \mathrm{~g})$ were ground in a mortar on ice with $0.15 \mathrm{M}$ PBS ( $\mathrm{pH}$ 7.2). The homogenate was centrifuged at $10,000 \mathrm{~g}$ for
10 minutes at $4{ }^{\circ} \mathrm{C}$ and the supernatant was filtered and collected. The protein assay was performed as described by Bradford (1976).

\section{Casein agar plate assay}

This assay was done as described by Yuan and Cole (1987), with some modifications: $0.5 \mathrm{~g}$ of agar in $46 \mathrm{ml}$ of $0.5 \mathrm{M}$ Tris buffer ( $\mathrm{pH}$ 6.5) was boiled and then cooled to approximately $50{ }^{\circ} \mathrm{C}$, and $4 \mathrm{ml}$ of casein $(0.5 \%$ in $1.0 \mathrm{M} \mathrm{NaOH})$ was added to it. This medium was divided between plates $(15 \mathrm{ml})$ and allowed to harden. Some wells were then constructed in agar and were filled with $50 \mu \mathrm{l}$ of a mixture of eggs and unfed tick larval extract and trypsin $(200 \mu \mathrm{g} / \mathrm{ml})$. The plates were incubated overnight at room temperature. Bright zones appeared around the wells after adding $3 \mathrm{ml}$ of acetic acid, thereby indicating the proteolytic activity.

\section{Serine protease inhibitor purification using affinity chromatography}

The trypsin-Sepharose column was prepared as specified by Hudson and Hay (1989), with some modifications. Sepharose (7 ml) was mixed with cyanogen bromide $(250 \mathrm{mg}$ in $2 \mathrm{ml}$ of distilled water) and the $\mathrm{pH}$ was adjusted to 11 using $\mathrm{NaOH}$ $(0.2 \mathrm{M})$ for $10 \mathrm{~min}$. The Sepharose was then washed with $0.1 \mathrm{M}$ borate saline buffer ( $\mathrm{pH} 8.3$ ). Trypsin $(50 \mathrm{mg}$ in $10 \mathrm{ml}$ of borate saline buffer) was added to the activated Sepharose and was kept at $4{ }^{\circ} \mathrm{C}$ overnight, then washed with $\mathrm{PBS}(0.15 \mathrm{M}, \mathrm{pH} 7.2)$. The trypsin-Sepharose was mixed with glycine (1 M, pH 8.0) for one hour and was washed with $40 \mathrm{ml}$ of PBS. Then, the trypsin-Sepharose was poured into the column and larval protein (30 mg) was applied to the column, with incubation at room temperature for 45 minutes, followed by washing with PBS. The inhibitors that had bonded were eluted with $0.1 \mathrm{M}$ glycine buffer ( $\mathrm{pH} 2.5$ ) containing $4 \mathrm{M}$ urea and were immediately neutralized with $2 \mathrm{M}$ Tris-HCl buffer ( $\mathrm{pH} 8$ ). The fractions were pooled and concentrated using centrifugal filter tubes (Eppendorf) with a molecular cutoff of $4 \mathrm{kDa}$.

\section{SDS-PAGE and western blotting}

Electrophoresis on $12 \%$ SDS polyacrylamide gel in the absence of 2-mercaptoethanol (2-ME) was carried out as described by Laemmli (1970), using $10 \mu$ g protein. The gels were stained with Coomassie blue and silver. Western blotting was performed as prescribed by Wang and Nuttall (1994). Gel containing resolved proteins was transferred electrophoretically to nitrocellulose membrane. The membrane was blocked for $45 \mathrm{~min}$, by means of PBS containing 2.5\% Tween 20, and all the washing steps were carried out with PBS containing $0.05 \%$ Tween $20(3 \times 5 \mathrm{~min})$. The membrane was incubated in serum derived from calves that had been experimentally infested with $R$. (B.) annulatus larvae (1:50 in PBS containing $0.05 \%$ Tween 20) for 1 hour at room temperature. It was then washed and incubated with anti-bovine IgG coupled with horseradish peroxidase (1/1000 in PBS) for $30 \mathrm{~min}$ at room temperature. After washing, the color development step was performed with diaminobenzidine containing $\mathrm{H}_{2} \mathrm{O}_{2}$. 


\section{One-dimensional reverse zymography}

Serine protease inhibitors were separated using polyacrylamide gel electrophoresis (gel contained $0.1 \%$ gelatin) and the Laemmli buffer system. $20 \mu \mathrm{l}$ of samples containing $1000 \mu \mathrm{g}$ of protein per $\mathrm{ml}$ were mixed with $20 \mu \mathrm{l}$ of sample buffer without reducing reagents and loaded $(10 \mu \mathrm{l})$. After electrophoresis, the gel slab was incubated in $0.1 \mathrm{M}$ Tris- $\mathrm{HCl}$ buffer $(\mathrm{pH} 8.0)$ containing trypsin $(10 \mu \mathrm{g} / \mathrm{ml})$ for $2 \mathrm{~h}$ at room temperature. The gels were then stained with Coomassie blue R-250 (PRUETT et al., 2008).

\section{Two-dimensional reverse zymography}

Isoelectric focusing (IEF) was performed as described by Yatsuda et al. (2003), using 7-cm immobilized pH gradient (IPG) strips (non-linear $\mathrm{pH}$ range 3-10). Samples containing $300 \mu \mathrm{g}$ of proteins were diluted in rehydration buffer (total volume $120 \mu \mathrm{l}$ ) and used to rehydrate the strips for $18 \mathrm{~h}$ at room temperature. IEF was performed in a Protean IEF cell (Bio Rad) under conditions recommended by the manufacturer. The IPG strips were then equilibrated for $20 \mathrm{~min}$ at room temperature in equilibration buffer (6 M urea, 30\% glycerol, 2\% SDS, $50 \mathrm{mM}$ Tris; $\mathrm{pH} 8.8$ ). The equilibrated IPG strips were transferred onto the gel, and SDS-PAGE for reverse zymography was carried out.

\section{Results}

\section{Casein agar plate assay}

In order to confirm the presence of serine protease inhibitors, the casein agar plate assay method was applied. As is shown in Figure 1, the absence of bright zones around wells 1 and 2 in plate A after adding acetic acid indicated that there was inhibition of proteolytic activity due to presence of trypsin inhibitor in tick egg

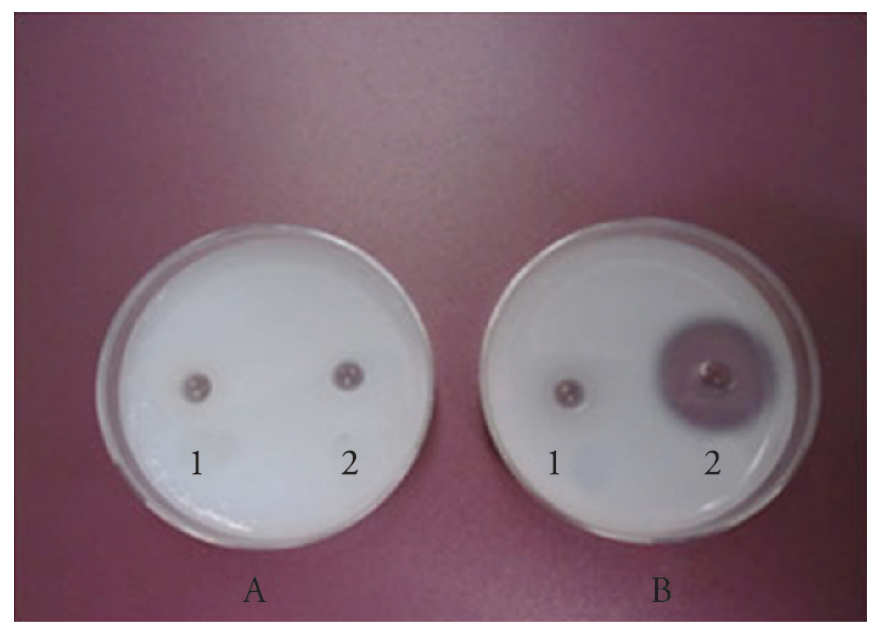

Figure 1. Proteolytic inhibition activity on agar plates containing casein as substrate: well containing mixture of unfed tick larvae extract and trypsin (A-1); well containing mixture of tick egg extract and trypsin (A-2); well containing PBS as negative control (B-1); well containing trypsin as positive control (B-2). and larval extracts. The presence of a bright zone around well 2 in plate B was due to trypsin proteolytic activity.

\section{SDS-PAGE}

To profile the tick proteins, larval extract was resolved by means of non-reducing SDS-PAGE, and eight sharp bands with molecular weights between 40 and $>250 \mathrm{kDa}$ were detected (Figure 2).

Through the non-reducing SDS-PAGE method for $R$. (B.) annulatus larval extract using silver staining, several bands with molecular weights between 12 and $>250 \mathrm{kDa}$ were observed (Figure 3).

\section{Western blotting}

The serum immunoreactivity of the calves that had been experimentally infested with tick larvae was detected by means of western blotting. Five protein bands at 48, 70, 110, 130 and $250 \mathrm{kDa}$ produced positive reactions with immune serum (Figure 4).

\section{Reverse zymography}

To detect serine protease inhibitors, reverse zymography of larval extracts was applied. Analysis on one-dimensional reverse zymography of larval extracts showed that there was trypsin inhibitory activity between 13 and $40 \mathrm{kDa}$. The blue zones with a bright background that were seen using Coomassie blue staining were indicative of trypsin inhibitory activity (Figure 5).

Analysis on two-dimensional reverse zymography of larval extracts showed that was trypsin inhibitory activity mainly between

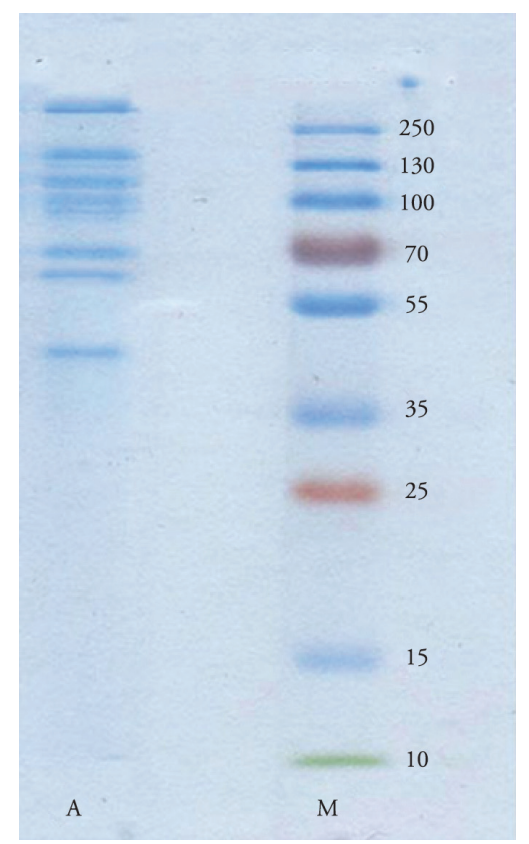

Figure 2. Non-reducing SDS-PAGE (12\%) profile of unfed $R$. (B.) annulatus larval extract (Coomassie blue staining): tick larval extract (lane A); molecular weight standards (lane M). 


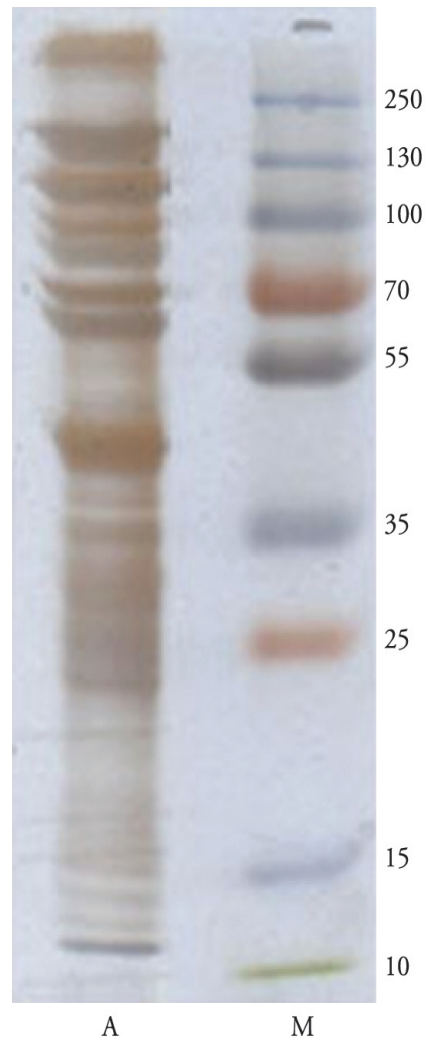

Figure 3. Non-reducing SDS-PAGE (12\% gel) on $R$. (B.) annulatus larval extract, using silver staining: tick larval extract (lane A); molecular weight standards (lane M).

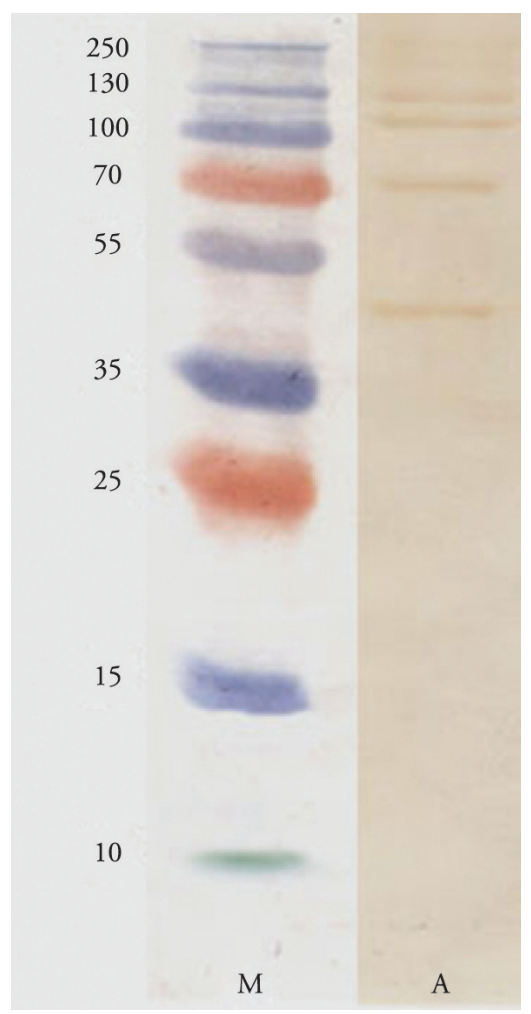

Figure 4. Unfed $R$. (B.) annulatus larval extract analyzed using western blotting: molecular weight standards (lane $\mathrm{M}$ ); tick larval extract (lane A).

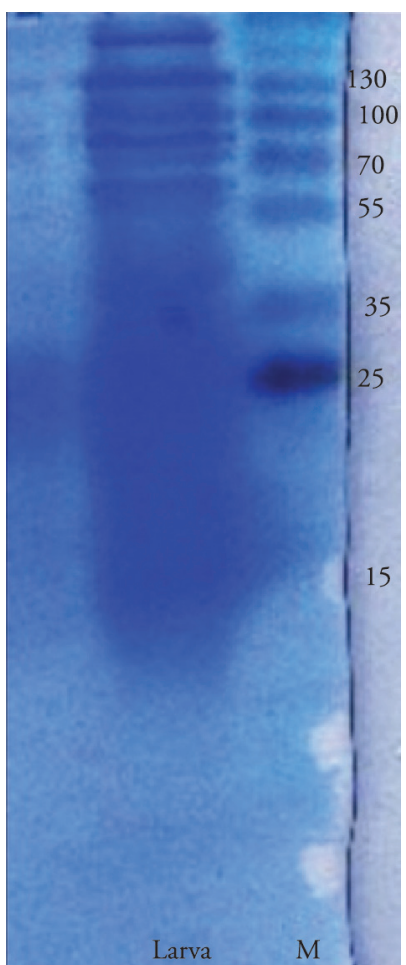

Figure 5. One-dimensional reverse zymography analysis on serine protease inhibitors of $R$. (B.) annulatus larval extracts: molecular weight standards (M). The gel was stained using Coomassie blue R 250.

13 and $40 \mathrm{kDa}$, at different isoelectric $\mathrm{pH}$ values (3-10). The blue zones with a bright background that were seen using Coomassie blue staining were indicative of trypsin inhibitory activity (Figure 6).

Using non-reducing SDS-PAGE for proteins that were purified by means of trypsin-Sepharose affinity chromatography, some protein bands with molecular weights between 13 and $34 \mathrm{kDa}$ were detected through Coomassie blue and silver staining (Figure 7).

Reverse zymography for proteins that were purified by means of trypsin affinity chromatography showed some blue zones in a bright field, with molecular weights between 13 and $34 \mathrm{kDa}$, through Coomassie blue staining (Figure 8).

\section{Discussion}

$R$. (B.) annulatus is an important tick in meso-Mediterranean climates. In Iran, this tick is distributed in the northern provinces and has an important role in transmission of some pathogens. Novel control methods such as vaccination have been developed recently. Any new biochemical and physiological information about ticks may help in developing new vaccine. Tick larvae have been shown to be important sources of trypsin and chymotrypsin inhibitors (WILLADSEN; RIDING, 1979; WILLADSEN; MCKENNA, 1983; TANAKA et al., 1999; ANDREOTTI et al., 2001). There are reports suggesting that serine protease inhibitors may be candidates for use in vaccines and that such vaccines would be effective (MULENG et al., 2001; IMAMURA et al., 2005). The inhibitory activities of these proteins relating to blood 


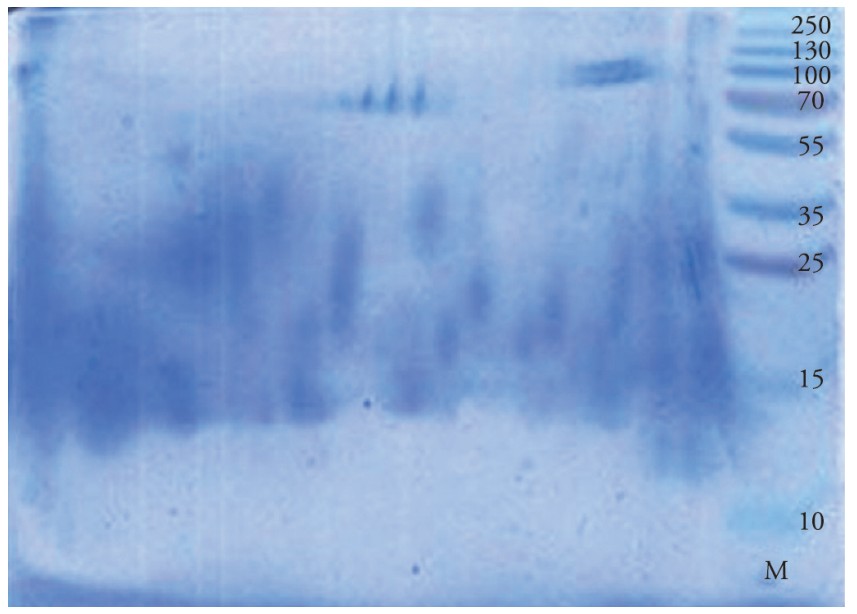

Figure 6. Two-dimensional reverse zymography analysis on serine protease inhibitors of $R$. (B.) annulatus larval extracts: molecular weight standards (M). The gel was stained using Coomassie blue R 250.

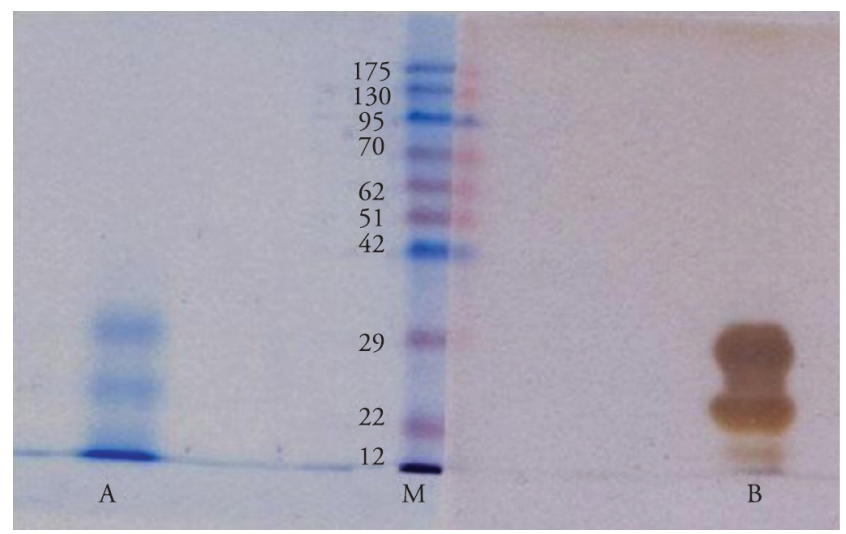

Figure 7. SDS polyacrylamide gel electrophoresis (12\%) on $R$. (B.) annulatus larvae serine protease inhibitors purified by means of trypsin-Sepharose: stained using Coomassie blue (A); stained using silver (B); molecular weight standards (M).

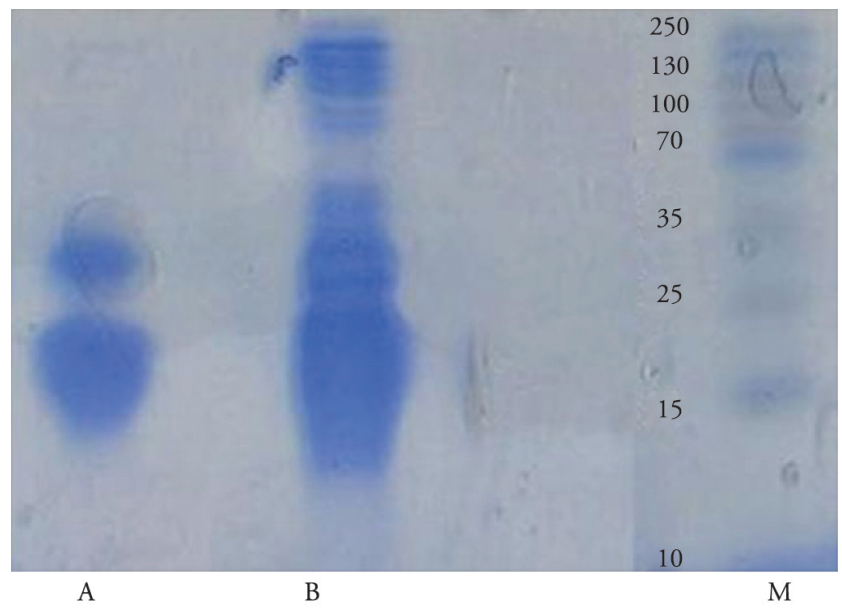

Figure 8. One-dimensional reverse zymography analysis on serine protease inhibitors of $R$. (B.) annulatus larval extracts purified by means of trypsin-Sepharose affinity chromatography (A) and whole larval extract (B); molecular weight standards (M). The gel was stained using Coomassie blue R250. clotting and inflammatory responses may facilitate ticks' blood sucking process.

In the present study, non-reducing SDS-PAGE was firstly performed on $R$. (B.) annulatus larval extract and eight sharp bands with molecular weights between 40 and $>250 \mathrm{kDa}$ were obtained using Coomassie staining. Several bands with molecular weights between 12 and > $250 \mathrm{kDa}$ were observed using silver staining. In the second step, we characterized and purified serine protease inhibitors from $R$. (B.) annulatus larval extracts. Through one and two-dimensional reverse zymography, larval extracts showed trypsin inhibitory activity mainly between 13 and $40 \mathrm{kDa}$, at different isoelectric $\mathrm{pH}$ values (3-10). The purified serine protease inhibitors presented molecular masses between 13 and $34 \mathrm{kDa}$.

Serine protease inhibitors are classified into at least 18 families based on the primary and three-dimensional structures and inhibition mechanisms (LASKOWSKI; QASIM, 2000). Six of these families, comprising Kazal, BPTI-Kunitz, $\alpha$-macroglobulin, serpin, pacifastin and Bombyx, are present in invertebrate hemolymph and also in saliva (KANOST, 1999; PHAM et al., 1996; SIMONET et al., 2002). Sasaki et al. (2004) purified serine protease inhibitors with molecular weights between 6 and $18 \mathrm{kDa}$ from $R$. (B.) microplus larvae by means of trypsin-Sepharose affinity chromatography. All fractions presented trypsin inhibitory activity, and some of them also inhibited human plasma kallikrein and human neutrophil elastase. Based on amino acid sequence data, these authors classified them as members of the Kunitz-type serine proteinase inhibitor family. In addition, other results have shown that serine proteinase inhibitors from $R$. sanguineus with molecular weights between 8 and $18 \mathrm{kDa}$ have inhibitor activity similar to that of $R$. (B.) microplus inhibitors (SANT'ANNA AZZOLINI et al., 2003). The variations in the molecular weights of serine protease inhibitors in different tick species may be due to the presence of different genes encoding these proteins, which may contain variable numbers of Kunitz domains (CORRALRODRÍGUEZ et al., 2009). Alternatively, they may be due to proteolytic processing of large Kunitz-type inhibitors during larval development (SASAKI et al., 2004).

An efficient immune response against serine proteinase inhibitors and neutralization of their enzymatic activity may influence blood feeding and tick survival (PREVOT et al., 2007). Our western blot results suggested that the calves that had been experimentally infected with ticks did not produce antibodies against serine proteinase inhibitors (in the range of $13-40 \mathrm{kDa}$ ). This result was in agreement with Andreotti et al. (2001) and Pruett et al. (2008). Lack of antibody induction against serine protease inhibitors in cattle during tick infestation may be due to the low amounts of these inhibitors introduced for immune response stimulation in the host. It may also be due to bovine unresponsiveness to them as a result of natural exposure via saliva, or due to antibody production at very low concentrations that are undetectable with the western blot method (PRUETT et al., 2008).

Animals have been immunized using purified serine proteinase inhibitors from different tick tissues and larvae in several studies. Experimental challenges performed on animals previously immunized with tick larvae have shown that the animals acquired significant protective immunity against ticks, with reduction of the 
biological parameters that would favor ticks (ANDREOTTI et al., 2001; PREVOT et al., 2007).

Development of new vaccines relies on characterization of tick proteins. Serine protease inhibitors have fundamental physiological roles in ticks and play an important role in tick-host interactions. Therefore, these proteins can be considered to be potential candidates for use in vaccines. It seems that further studies are needed in order to characterize and identify tick larval proteins.

\section{Acknowledgements}

This study was supported by a grant from Tehran University.

\section{References}

Andreotti R, Malavazi-Piza KC, Sasaki SD, Torquato RJ, Gomes A, Tanaka AS. Serine proteinase inhibitors from eggs and larvae of tick Boophilus microplus: purification and biochemical characterization. $J$ Protein Chem 2001; 20(5): 337-343. PMid:11732684. http://dx.doi. org/10.1023/A:1012242817869

Arocha-Piñango CL, Marchi R, Carvajal Z, Guerrero B. Invertebrate compounds acting on the hemostatic mechanism. Blood Coagul Fibrinolysis 1999; 10(2): 43-68. http://dx.doi.org/10.1097/00001721199903000-00001

Bradford MM. A rapid and sensitive method for quantitation of microgram quantities of protein utilizing the principle of proteindye binding. Ann Biochem 1976; 72(1-2): 248-254. http://dx.doi. org/10.1016/0003-2697(76)90527-3

Brown SJ, Shapiro SZ, Askenase PW. Characterization of tick antigens inducing host immune resistance. I. Immunization of guinea pigs with Amblyomma americanum-derived salivary gland extracts and identification of an important salivary gland protein antigen with guinea pig anti-tick antibodies. J Immunol 1984; 133(6): 3319-3325. PMid:6491289.

Corral-Rodríguez MA, Macedo-Ribeiro S, Barbosa Pereira PJ, FuentesPrior P. Tick-derived Kunitz-type inhibitors as antihemostatic factors. Insect Biochem Mol Biol 2009; 39(9): 579-595. PMid:19631744. http:// dx.doi.org/10.1016/j.ibmb.2009.07.003

Estrada-Peña A, Bouattour A, Camicas JL, Walker AR. Ticks of domestic animals in the Mediterranean region. A guide to identification of species. Zaragoza: University of Zaragoza Press; 2004.

Hudson L, Hay FC. Practical Immunology. 3. Oxford: Blackwell Scientific Publications; 1989

Ibrahim MA, Ghazy AH, Maharem T, Khalil M. Isolation and properties of two forms of thrombin inhibitor from the nymphs of the camel tick Hyalomma dromedarii (Acari: Ixodidae). Exp Appl Acarol 2001; 25(8): 675-698. PMid:12171275. http://dx.doi. org/10.1023/A:1016136207308

Imamura S, Da Silva Vaz Junior I, Sugino M, Ohashi K, Onuma M. A serine protease inhibitor (serpin) from Haemaphysalis longicornis as an anti-tick vaccine. Vaccine 2005; 23(10): 1301-1311. PMid:15652673. http://dx.doi.org/10.1016/j.vaccine.2004.08.041

Kanost MR. Serine proteinase inhibitors in arthropod immunity. Dev Comp Immunol 1999; 23(4-5): 291-301. http://dx.doi.org/10.1016/ S0145-305X(99)00012-9
Laemmli UK. Cleavage of structural proteins during the assembly of the head of bacteriophage T4. Nature 1970; 227(5259): 680-685. PMid:5432063. http://dx.doi.org/10.1038/227680a0

Laskowski M, Qasim MA. What can the structures of enzyme-inhibitor complexes tell us about the structures of enzyme substrate complexes? Biochim Biophys Acta 2000; 1477(1-2): 324-337. http://dx.doi. org/10.1016/S0167-4838(99)00284-8

Muleng A, Sugino M, Nakajim M, Sugimoto C, Onuma M. TickEncoded serine proteinase inhibitors (serpins); potential target antigens for tick vaccine development. J Vet Med Sci 2001; 63(10): 1063-1069. PMid:11714020. http://dx.doi.org/10.1292/jvms.63.1063

Pham TN, Hayashi K, Takano R, Itoh M, Eguchi M, Shibata H, et al. A new family of serine protease inhibitors (Bombyx family) as established from the unique topological relation between the positions of disulphide bridges and reactive site. J Biochem 1996; 119(3): 428-434. PMid:8830035. http://dx.doi.org/10.1093/oxfordjournals.jbchem. a021259

Prevot PP, Couvreur B, Denis V, Brossard M, Vanhamme L, Godfroid E. Protective immunity against Ixodes ricinus induced by a salivary serpin. Vaccine 2007; 25(17): 3284-3292. PMid:17270322. http://dx.doi. org/10.1016/j.vaccine.2007.01.008

Pruett JH, Olafson PU, Davey RB. Serologically defined Rhipicephalus (Boophilus) micropolus larval antigens in BmLF3, a partially pure Sephacryl S-300 fraction of crude larval proteins. Vet Parasitol 2008; 155(3-4): 264272. PMid:18562121. http://dx.doi.org/10.1016/j.vetpar.2008.04.020

Sant'Anna Azzolini S, Sasaki SD, Torquato RJ, Andreotti R, Andreotti E, Tanaka AS. Rhipicephalus sanguineus trypsin inhibitors present in the tick larvae: isolation, characterization, and partial primary structure determination. Arch Biochem Biophys 2003; 417(2): 176-182. http:// dx.doi.org/10.1016/S0003-9861(03)00344-8

Sasaki SD, Azzolini SS, Hirata IY, Andreotti R, Tanaka AS. Boophilus microplus tick larvae, a rich source of Kunitz type serine proteinase inhibitors. Biochimie 2004; 86(9-10): 643-649. PMid:15556274. http:// dx.doi.org/10.1016/j.biochi.2004.09.010

Sauer JR, McSwain JL, Bowman AS, Essenberg RC. Tick salivary gland physiology. Annu Rev Entomol 1995; 40: 245-267. PMid:7810988. http://dx.doi.org/10.1146/annurev.en.40.010195.001333

Simonet G, Claeys I, Broeck JV. Structural and functional properties of a novel serine protease inhibiting peptide family in arthropods. Comp Biochem Physiol B Biochem Mol Biol 2002; 132(1): 247-255. http:// dx.doi.org/10.1016/S1096-4959(01)00530-9

Tanaka AS, Andreotti R, Gomes A, Torquato RJ, Sampaio MU, Sampaio CA. A double headed serine proteinase inhibitor--human plasma kallikrein and elastase inhibitor-- from Boophilus microplus larvae. Immunopharmacology 1999; 45(1-3): 171-177. http://dx.doi. org/10.1016/S0162-3109(99)00074-0

Vermeulen NM, Viljoen GJ, Bezuidenhout JD, Visser L, Neitz AW. Kinetic properties of toxic protease inhibitors isolated from tick eggs. Int J Biochem 1988; 20(6): 621-631. http://dx.doi.org/10.1016/0020711X(88)90102-4

Wang H, Nuttall PA. Comparison of the proteins in salivary glands, saliva and haemolymph of Rhipicephalus appendiculatus female ticks during feeding. Parasitology 1994; 109(Pt 4): 517-523. PMid:7794318. http:// dx.doi.org/10.1017/S003118200008077X 
Willadsen P, Riding GA. Characterization of a proteolytic-enzyme inhibitor with allergenic activity. Multiple functions of a parasitederived protein. Biochem J 1979; 177(1): 41-47. PMid:426780 PMCid:PMC1186338.

Willadsen P, McKenna RV. Trypsin-chymotrypsin inhibitors from the tick, Boophilus microplus. Aust J Exp Biol Med Sci 1983; 61(Pt 2): 231238. PMid:6683962. http://dx.doi.org/10.1038/icb.1983.21
Yatsuda AP, Krijgsveld J, Cornelissen AW, Heck AJ, De Vries E. Comprehensive analysis of the secreted proteins of the parasite Haemonchus contortus reveals extensive sequence variation and differential immune recognition. J Biol Chem 2003; 278(19): 1694116951. PMid:12576473. http://dx.doi.org/10.1074/jbc. M212453200

Yuan L, Cole GT. Isolation and characterization of an extracellular proteinase of Coccidioides immitis. Infect Immun 1987; 55(9): 1970-1978. PMid:3305358 PMCid:PMC260642. 